\title{
ターボジャブの空力特性の計測*
}

\author{
長尾 将史 ${ }^{* 1}$, 中嶋 智也 ${ }^{* 2}$, 板野 智昭 ${ }^{* 3}$, 関 眞佐子 ${ }^{* 4}$
}

\section{Experimental Studies on Aerodynamic Characteristics of the Turbo-Jav}

\author{
Masashi NAGAO, Tomoya NAKAJIMA, Tomoaki ITANO and Masako SUGIHARA-SEKI*4 \\ ${ }^{* 4}$ Kansai University, Department of Pure and Applied Physics \\ 3-3-35 Yamate-cho, Suita, Osaka, 564-8680 Japan
}

In order to improve the record of the javelic throw in the junior Olympic games, it is important to elucidate the flight characteristics of the "turbo-jav" used in this throwing event. Unlike the spear used in the javelin throw, the turbo-jav has four tail fins. Focusing on the effect of the fins, we investigate the flight characteristics of the turbo-jav, by means of wind tunnel tests, throwing experiments and numerical simulations. In the wind tunnel test, we measured the drag force, lift force and pitching moment acting on intact turbo-javs as well as turbo-javs with their fins cut, in a low speed wind tunnel at the flow speed up to $25 \mathrm{~m} / \mathrm{s}$. The experimental results showed that the drag and lift coefficients for the intact turbo-javs are larger than the corresponding values for the turbo-javs without fins. As the angle of attack increases from 0 , the moment coefficients for the intact turbo-javs decrease from 0 , whereas the moment coefficients for the turbo-javs without fins increase. In accord with this property for the pitching moment, the throwing experiments showed that intact turbo-javs fly stably with oscillating angle of attack around 0 . The flying distance, the orbit and the variation of angle of attack for the intact turbo-javs launched by a launcher agree closely with the numerical simulation performed based on the wind tunnel test. A comparison of throwing experiments by an athlete and by the launcher suggested that the turbo-javs flying without rolling could reach farther than turbo-javs with rolling.

Key Words : Turbo-Javs, Sports Engineering, Flow Drag, Wind Tunnel Tests, Tail Fins

\section{1. 緒言}

ターボジャブは，槍投げと同様に飛距離を競う競技で，ジュニアオリンピックの正式競技であるジャベリック スローに用いられる用具である. ターボジャブは後尾に 4 枚の羽を有する点が槍投げのヤリと大きく異なる特徵 となっている，これまでの有翼の飛翔体についての研究は，主にロケットなど飛行速度が大きくレイノルズ数が 高い場合が中心である，飛行速度が小さい場合については，低レイノルズ数における翼特性に関する研究(1)や安 定翼を有する細長体である水口ケットの飛行についての研究(2)-(5)などが見られる。しかし，推力をもたず凹らの ある本体をもつ投擲飛翔体であるターボジャブについては，リリース時の初期条件などの飛距離を決める因子を 検討した研究 ${ }^{(6)(7)}$ においてヤリの飛行との特性の違いが報告されているものの, 安定翼に注目した流体力学的な観 点からの研究はなされていない. 本研究では羽の影響に着目し, 羽の有無によるターボジャブの空力特性の差異 を風洞実験により計測し，得られた空力特性をもとに数值シミュレーションを行ってターボジャブの飛行軌道を 計算して，投射実験で得られた飛行軌道との比較・検討によりターボジャブの飛行特性を調べたので報告する.

\footnotetext{
* 原稿受付 2013 年 3 月 27 日

${ }^{* 1}$ 関西大学大学院理工学研究科（广564-8680 大阪府吹田市山手町 3-3-35）

*2 正員, 大阪府立大学 学術研究院 第二学群 (機械系)

*3 関西大学システム理工学部

${ }^{* 4}$ 正員, 関西大学システム理工学部

E-mail: sekim@kansai-u.ac.jp
} 
(a)

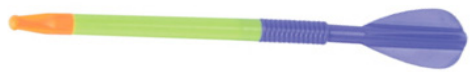

(b)

Fig. 1 Photographs of (a) an intact turbo-jav, and (b) a turbo-jav with its fins cut.

Table 1 Data of turbo-javs with and without fins.

\begin{tabular}{|c|c|c|c|c|c|}
\hline & $\begin{array}{c}\text { Length } \\
{[\mathrm{m}]}\end{array}$ & $\begin{array}{c}\text { Mass } \\
{[\mathrm{kg}]}\end{array}$ & $\begin{array}{c}\text { Diameter } \\
{[\mathrm{m}]}\end{array}$ & $\begin{array}{c}\text { Center of mass(distance from the tip) } \\
{[\mathrm{m}]}\end{array}$ & $\begin{array}{c}\text { Moment of inertia } \\
{\left[\mathrm{kg} \cdot \mathrm{m}^{2}\right]}\end{array}$ \\
\hline Intact turbo-javs & $6.96 \times 10^{-1}$ & $3.075 \times 10^{-1}$ & $3.72 \times 10^{-2}$ & $3.83 \times 10^{-1}$ & $1.33 \times 10^{-2}$ \\
\hline Turbo-javs without fins & $6.96 \times 10^{-1}$ & $2.561 \times 10^{-1}$ & $3.72 \times 10^{-2}$ & $3.29 \times 10^{-1}$ & $9.10 \times 10^{-3}$ \\
\hline
\end{tabular}

\section{2. 実 験 方 法}

ターボジャブは，本体がポリエチレン製，先端がエストラマー製で内部は中空構造になっている．一般の槍投 げ競技用のヤリと比較して長さは短く，直径は大きく，軽量で，後尾に互いに直交する 4 枚の羽を持つ. 本研究 で用いたターボジャブを図1に示寸. 図1 (a)は通常のターボジャブ(ターボジャブVII 300g, ニシ・スポーツ T5109, 以下“羽あり”) で, 図 1 (b)は羽の影響を調べるために羽を切り落としたターボジャブ (以下 “羽なし”) である. 表 1 にそれぞれの仕様を示す。ここで，慣性モーメントは重心を通る，ターボジャブの軸に対して垂直な軸まわ りの慣性モーメントを表し，その值は２点吊り法により計測した.

\section{$2 \cdot 1$ 風洞実験による空力特性の計測}

風洞実験は, 大阪府立大学工学部機械工学科の最大風速約 $25 \mathrm{~m} / \mathrm{s}$, 断面 $1.0 \mathrm{~m} \times 1.5 \mathrm{~m}$, 長さ $3.0 \mathrm{~m}$ の変形八角形 断面測定部を持つゲッチンゲン型低速風洞装置を用いた。測定部上部には 3 分力天称装置が設置されている. 図 2 に示寸ように，ターボジャブは重心位置を回転支持し，抗力 $D$ と揚力 $L$ ，およびピッチングモーメント $M$ を計 測した (2 点支持). サブストラットの影響を考慮し，抗力と揚力に対して，メインストラットのみで支持する 1 点支持計測も行った，ストラットはアルミ製で，流線型の断面形状をもつ.

迎え角 $\alpha$ は一様流方向を基準とし，ターボジャブ全長 $l$ を代表長さとするレイノルズ数 $R \mathrm{e}=U l / v$ (一様風 速 $U$, 空気の動粘性率 $v)$ を用いる. 抗力係数 $C_{\mathrm{d}}$, 揚力係数 $C_{\mathrm{l}}$, モーメント係数 $C_{\mathrm{m}}$ は, 抗力 $D$, 揚力 $L$, モー メント $M$ を用いて次のように定義する.

$$
\begin{aligned}
& C_{d}=\frac{D}{(1 / 2) \rho U^{2} S} \\
& C_{l}=\frac{L}{(1 / 2) \rho U^{2} S} \\
& C_{m}=\frac{M}{(1 / 2) \rho U^{2} S(l / 2)}
\end{aligned}
$$

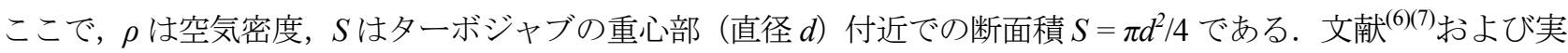
際の投射実験を参考に，風速 $U=12.5 \sim 25 \mathrm{~m} / \mathrm{s}$ ，迎え角 $\alpha=-10^{\circ} \sim 30^{\circ}$ の範囲で実験した。 “羽あり”ターボ ジャブの計測では，4 枚の羽のうち 2 枚が常に鉛直方向を向くように支持した．ストラットに作用する力の 抗力への影響を調べるため, 図 3 のようにメインストラット単体に働く抗力の計測も行なった. この際, タ 一ボジャブがあるときの流れを再現するため, 下方にターボジャブを設置した. 


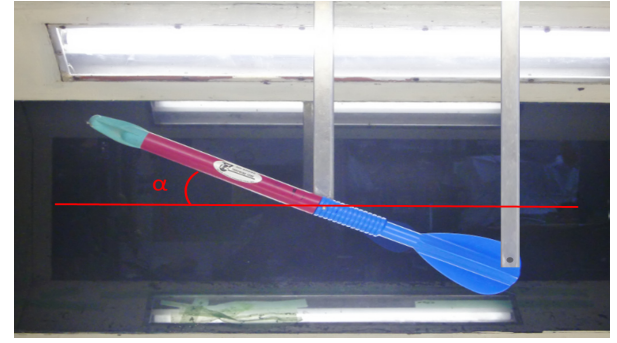

Fig. 2 Side view of the turbo-jav in the wind tunnel (two strut method for model support). The angle of attack is expressed as $\alpha$.

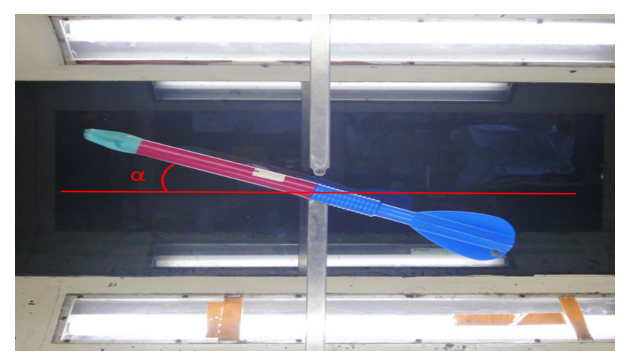

Fig. 3 Measurements of the drag force on the main strut. The turbo-jav is supported from the below for various angles of attack.

\section{$2 \cdot 2$ 投射実験による飛行軌道の計測}

投射実験は, (a) 投擲者が実際に投げる方法と,(b) 発射装置により射出する方法の2種類の実験方法で行った. 投擲者は槍投げの競技経験者(陸上部所属で投擲を専門とする)で，通常の投橂競技と同様の方法でターボジャブ を投射した。

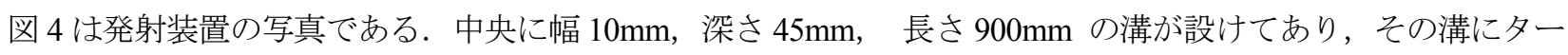
ボジャブの羽の 1 枚を入れ, 両端を発射台に固定しターボジャブの後尾部にあてたゴム（フィットネスバンド, ラテックス製）により溝に沿って射出できる．発射台は水平に対して任意の角度で固定できる．図 5 に投射実験 での撮影位置を示す. 投射実験は屋外で行い, 図 5 のように 2 台のデジタルカメラ (CASIO EX-F1:カメラ 1 とカ メラ 2)でターボジャブの飛行を撮影した．カメラ 1 はリリース時の初期条件を正確に得るため，投擲者（あるい

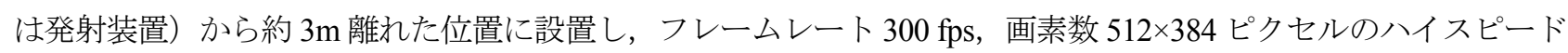
モードで撮影を行った. このとき空間分解能は $3.2 \sim 4.0 \mathrm{~mm} / \mathrm{pixel}$ であった. カメラ 2 は飛行軌道の全体が捉え

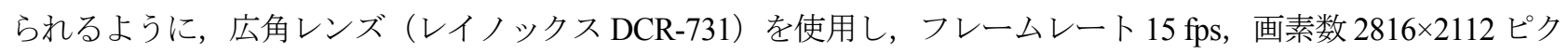
セルの静止画の連続写真モードで撮影を行った. 空間分解能は飛距離によって変わるがほぼ $10 \sim 12 \mathrm{~mm} / \mathrm{pixel}$ で あった。

撮影した画像は画像処理ソフト ImageJにより解析を行い, 各画像におけるターボジャブの重心位置と姿勢角 $\varphi$ （ターボジャブが水平方向に対してな寸角，図6参照）を求めた. 各画像の重心位置を連ねることにより重心軌 道を求めた. 重心軌道を 3 次スプラインで近似し，その接線の傾きから速度べクトルの方向 $\theta$ を得た．各画像の 姿勢角 $\varphi$ とこの角度 $\theta$ との差をとることにより, ターボジャブの迎え角 $\alpha$ を求めた(図 6 参照).

発射装置では，グラウンドに引かれた白線に沿ってターボジャブを射出する．このときターボジャブは白線上 に落下した．投擲者による投射では，白線上から投げ，落下地点が白線からずれていない場合のみを実験データ として採用した。 また, 風は熱式風速計（アイ電子技研 V-01-AND3）でモニターし, 風速が $0.3 \mathrm{~m} / \mathrm{s}$ 以下のとき を選んで実験を行い，気温は温度計(A\&D AD-5640A)で測定した。

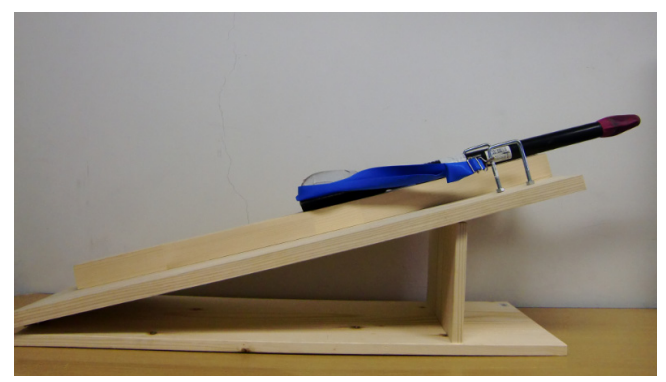

Fig. 4 Turbo-jav launcher.

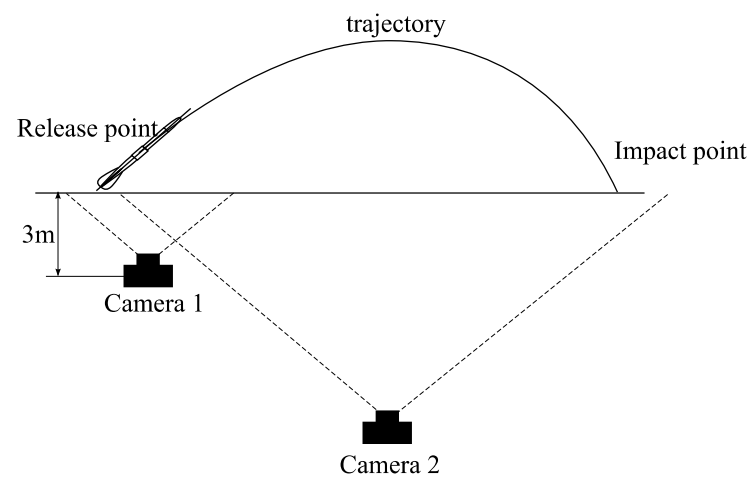

Fig. 5 Set-up for throwing experiments. 


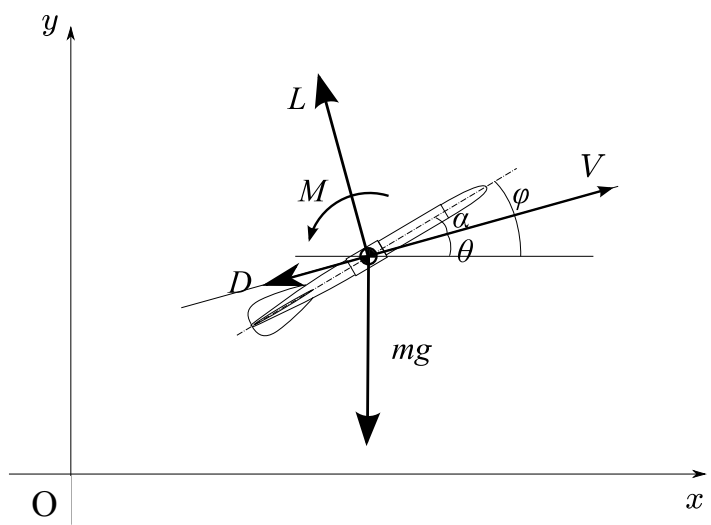

Fig. 6 Configuration of a flying turbo-jav( $\varphi$ : attitude angle, $\alpha$ : angle of attack, $\theta$ : angle of incidence).

\section{$2 \cdot 3$ 数値シミュレーション}

図 6 にターボジャブの飛行時の座標系を示す. ターボジャブは一つの鉛直面内で運動するものとし，水平方向 に $x$ 軸，鉛直上向きに $y$ 軸をとる.

$(x, y), \varphi$ を時刻 $t$ におけるターボジャブの重心位置と姿勢角とすれば, 抗力 $D$, 揚力 $L$, および重心まわりのモ ーメント $M$ が働いているとき, ターボジャブの並進運動と重心まわりの回転運動（ピッチング運動）は次式に従 う.

$$
\begin{aligned}
& m \frac{\mathrm{d}^{2} x}{\mathrm{~d} t^{2}}=-L \sin \theta-D \cos \theta \\
& m \frac{\mathrm{d}^{2} y}{\mathrm{~d} t^{2}}=L \cos \theta-D \sin \theta-m g \\
& I \frac{\mathrm{d}^{2} \varphi}{\mathrm{d} t^{2}}=M
\end{aligned}
$$

ここで， $m$ は質量で，Iは重心まわりの慣性モーメント, $g$ は重力加速度の大きさである.

風洞実験で得られた各空力係数 $C_{\mathrm{d}}, C_{\mathrm{l}}, C_{\mathrm{m}}$ を用いて $D, L, M$ の值を評価し, 式(4)〜(6)を数值的に解くことで ターボジャブの重心軌道と姿勢角および迎え角の変化を求めることができる. 本研究では, 各投射実験の初期条 件からスタートして式(4)〜(6)の時間発展を陽的に差分法により計算した. その結果と投射実験の結果との比較を 行った.

\section{3. 結 果 と 考 察}

\section{$3 \cdot 1$ 空力特性}

\section{（1）レイノルズ数依存性}

図 7 に“羽あり” ターボジャブの空力係数とレイノルズ数の関係を示す. 抗力係数 $C_{\mathrm{d}}$ と揚力係数 $C_{1}$ はメイン ストラットのみで支持し，モーメント係数 $C_{\mathrm{m}}$ はサブストラットを併用して計測した值である. ただし，これら

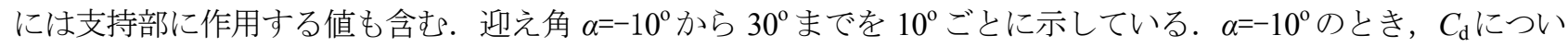
ては $\alpha=10^{\circ}$ の值とほぼ一致し, $C_{1}$ と $C_{\mathrm{m}}$ については絶対值がほぼ同じで符号が逆となった. 別に行った 2 点支持に より計測した揚力係数 $C_{1}$ の值は対応する 1 点支持の值とほぼ一致したものの，抗力係数 $C_{\mathrm{d}}$ の值は対応する 1 点 支持の值より常に大きくなった．これは主としてサブストラットに働く抗力の影響と考えられる. 図 7 より, 風 速 $U=12.5 \sim 25 \mathrm{~m} / \mathrm{s}$ に対応する $5.5 \times 10^{5}<R e<11 \times 10^{5}$ の範囲で，いずれの迎え角に対しても各空力係数の值はレイ 
ノルズ数に依存せず，ほぼ一定となることが分かる.“羽なし”ターボジャブについても各空力係数のレイノル ズ数依存性は見られなかった.

\section{（2）支持部(メインストラット)に働く抗力}

図 3 のようにターボジャブによる流れの影響に配慮してメインストラット単体に働く抗力を計測し, 式(1)によ りターボジャブの断面積を用いて抗力係数 $C_{\mathrm{d} 0}$ を評価した. 各迎え角に対し, 抗力係数とレイノルズ数の関係を 調べたところ， $5.5 \times 10^{5}<R e<11 \times 10^{5}$ の範囲において，抗力係数はほとんどレイノルズ数に依存しなかった．そこ で，このレイノルズ数の範囲において $C_{\mathrm{d} 0}$ の值を平均し，その平均值とターボジャブの迎え角 $\alpha$ との関係を求め 図 8 に示した. グラフのエラーバーは標準偏差を示している. 計測結果は迎え角 $\alpha$ にもほとんど依らない結果と なり，その平均值は $C_{\mathrm{d} 0}=0.465$ となった.

(a)

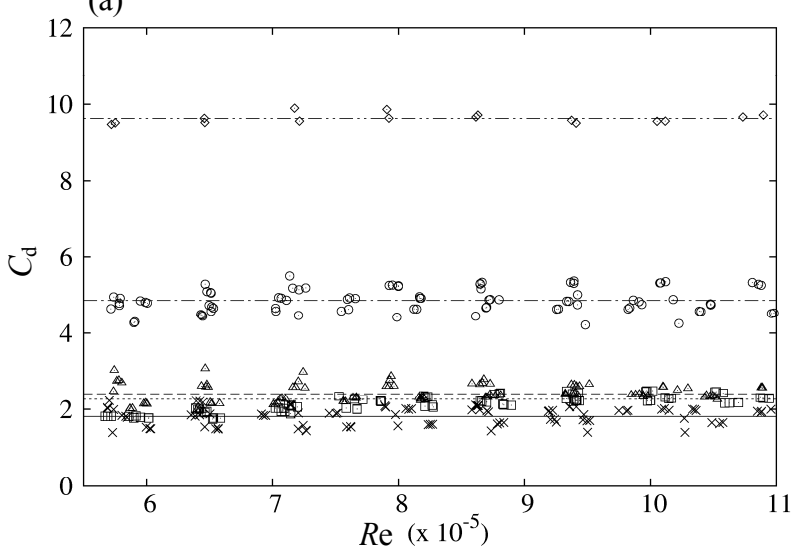

(c)

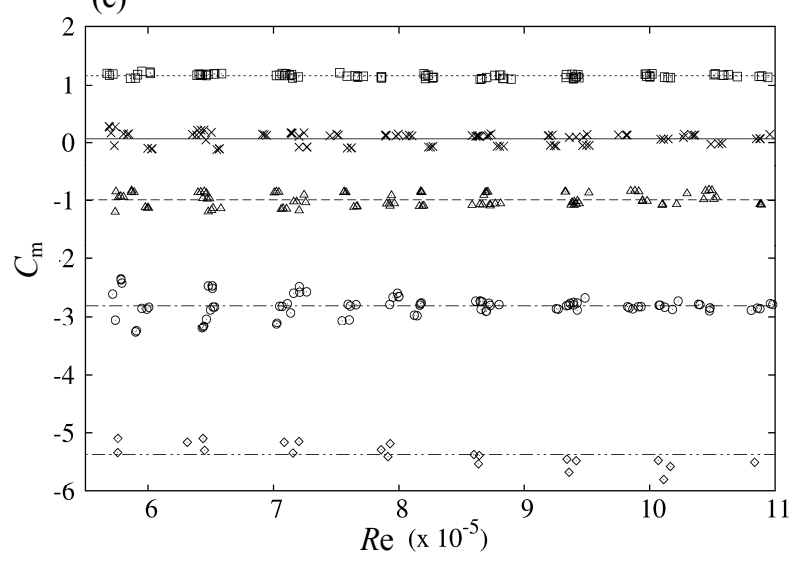

(b)

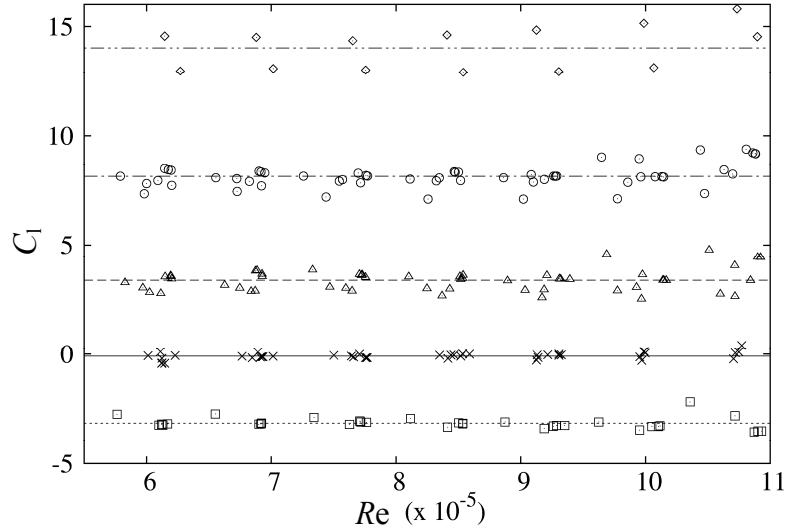

Fig. 7 (a) Drag coefficient, (b) lift coefficient, (c) moment coefficient for intact turbo-javs at $\alpha=-$ $10^{\circ}$ (square), $0^{\circ}$ (cross), $10^{\circ}$ (triangle), $20^{\circ}$ (circle), and $30^{\circ}$ (diamond). The averaged values are plotted by horizontal lines at $\alpha=-10^{\circ}$ (dotted line), $0^{\circ}$ (solid line), $10^{\circ}$ (dashed line), $20^{\circ}$ (dash dotted line), and $30^{\circ}$ (dash double dotted line).

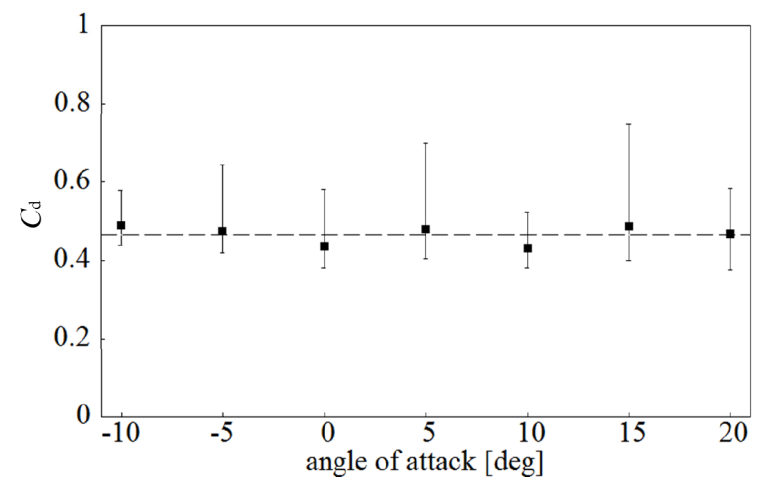

Fig. 8 Drag coefficient for the main strut. The dashed line represents the mean value $\left(C_{\mathrm{d} 0}=0.465\right)$. 


\section{（3）迎え角依存性}

各迎え角において空力係数が $5.5 \times 10^{5}<R e<11 \times 10^{5}$ の範囲でほぼ一定であったことから，“羽あり”ターボジャ ブに対する図 7 の結果および “羽なし” ターボジャブに対する同様の結果をこのレイノルズ数の範囲で平均し， その值を迎え角 $\alpha$ の関数として図 9 に示した．ただし，抗力係数については，図 7 の結果からメインストラット の抗力係数 $\mathrm{C}_{\mathrm{d} 0}$ を差し引いたものを示した. また, 図 7 で $\alpha= \pm 10^{\circ}$ の場合に対して述べたように, $|\alpha| \leq 10^{\circ}$ の 範囲で $C_{d}$ の值は $\alpha$ に対してほぼ対称となり， $C_{1}$ と $C_{\mathrm{m}}$ の值は $\alpha$ に対してほぼ反対称となったので， $\alpha$ が 0 および 正の場合の計測を繰り返して各係数の值を求め, その值を用いて $-30^{\circ} \leq \alpha<0^{\circ}$ についても描いた．ただし， $C_{d}$ は 4 次式、 $C_{1}$ と $C_{\mathrm{m}}$ は 3 次式で近似した.

羽の有無にかかか力らず, 抗力係数 $C_{\mathrm{d}}$ は $\alpha=0$ で最小值をとり $|\alpha|$ の増加とともに増大し, 揚力係数 $C_{1}$ は原点を通 る右上がりの曲線となった，それらの大きさは，常に“羽あり”ターボジャブの方が大きい．この結果は，“羽あ り”ターボジャブでは “羽なし”ターボジャブと比べ, 羽に働く空気力が抗力と揚力として加わるためと理解さ れる．揚抗比は “羽あり”ターボジャブに対して $10^{\circ}$ と $15^{\circ}$ の間で最大となったが，“羽なし”ターボジャブに対 しては $|\alpha|<30^{\circ}$ 範囲で $\alpha$ が大きくなるに従い単調に増加した。一方，モーメント係数 $C_{\mathrm{m}}$ は，“羽あり”ターボジ ヤブでは右下がりの曲線となるのに対し“羽なし”ターボジャブでは右上がりとなり，羽の有無で迎え角依存性 が逆の傾向を示した. これも羽に働く空気力に起因寸るものと考えられ，この結果から，“羽あり”ターボジャブ では，羽があることにより姿勢を安定化する向きにモーメントが働くことが分かる.

\section{$3 \cdot 2$ 投射実験と数值シミュレーションとの比較}

\section{(1) 投擲者による投射}

“羽あり”ターボジャブを投擲者が実際に投げて行った投射実験の結果の例を図 10 に示す. 図 10(a)は重心軌 道を表し，地表面を $y$ 座標の原点とし，ターボジャブのリリース位置を $x$ 座標の原点としている. 図 10(b)は，図 10(a)に対応寸る迎え角変化である. カメラ画像より得られた投射の初期条件は表 2 の通りである. また，表 2 の 条件を初期条件とする数值シミュレーションの結果を図 10 に実線で, 空気抵抗がない場合の質点の放物運動を破 線で示した。

(a)

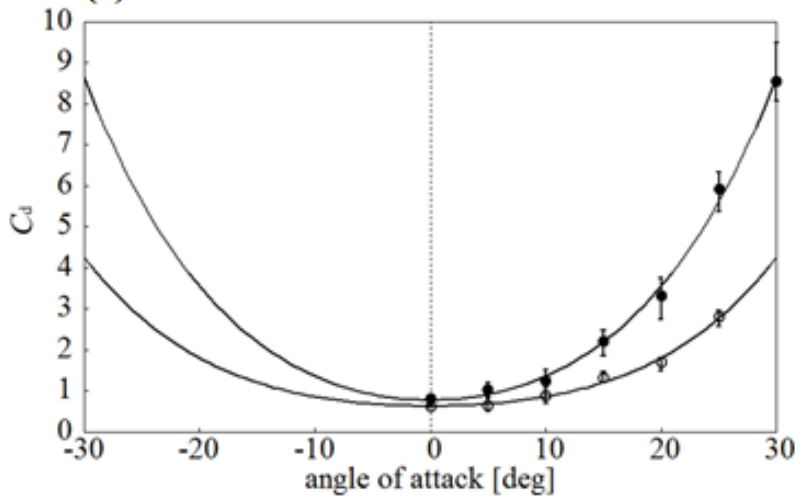

(c)

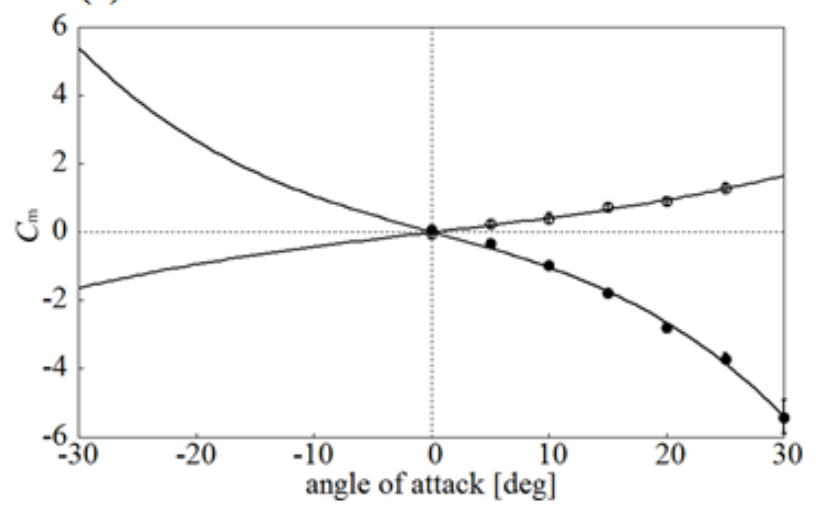

(b)

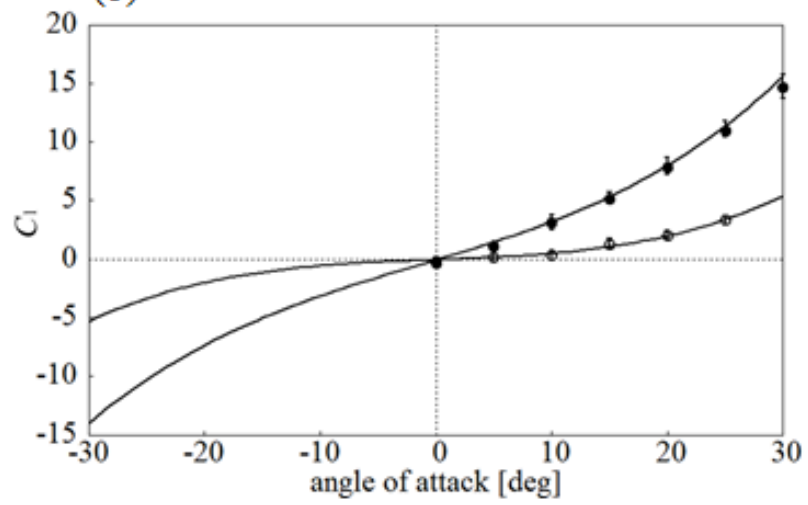

Fig. 9 (a) Drag coefficient, (b) lift coefficient, (c) moment coefficient for intact turbo-javs (filled circles) and turbo-javs without fins (open circles). 
(a)

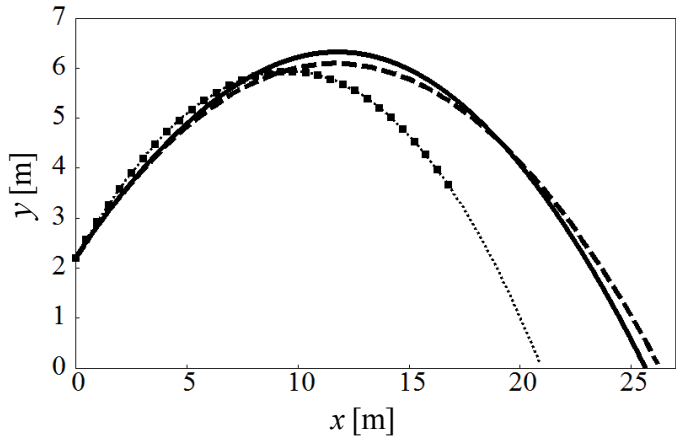

(b)

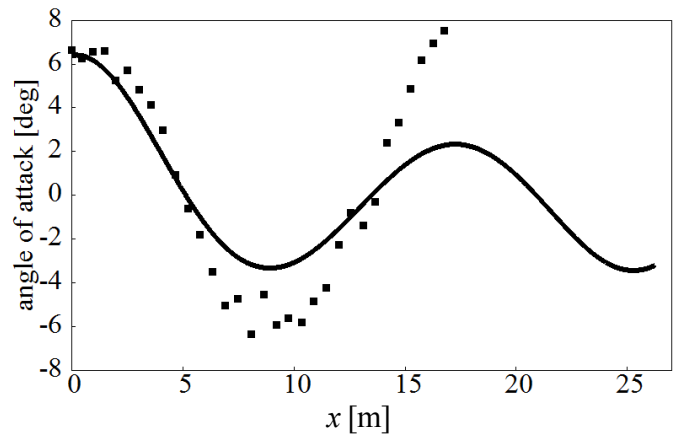

Fig. 10 (a) Trajectories of the center of mass, and (b) variations of angle of attack for an intact turbo-jav (dotted line: throwing experiment by an athlete, solid line: numerical simulation, dashed line: no-drag case).

Table 2 Initial conditions and flying distance for a throwing experiment by an athlete.

\begin{tabular}{|c|c|c|}
\hline \multirow{6}{*}{ Initial conditions } & Release height & 2.20 \\
\hline & Initial velocity & 15.75 \\
\hline & Attitude angle & 44.06 \\
\hline & Angle of incidence & 37.42 \\
\hline & Angle of attack & 6.63 \\
\hline & Angular velocity & -0.44 \\
\hline \multirow{3}{*}{ Flying distance } & Throwing experiment & 20.80 \\
\hline & Numerical simulation & 25.65 \\
\hline & No-drag case & 26.21 \\
\hline
\end{tabular}

図10(a)から, 投射実験と数值シミュレーションでは重心軌道が大きく異なることが分かる. 表 2 に示すように， 飛距離も両者で大きく異なり，数值シミュレーションの方が大きな值となった. この差異は軸まわりの回転運動 に起因するものと考えられるが，その詳細については次節で考察する.

図 10(a)と表 2 より，“羽あり” ターボジャブを投擲者が投げた場合，実際の飛距離は空気抵抗がない場合より 小さいことが分かる.この傾向は一般的に成り立ち, 前田らの先行研究 ${ }^{(6)(7)}$ の結果とも一致している. 一方，槍投 げの場合は，実際のヤリの飛距離の方が空気抵抗がない場合よりも大きくなることが報告されている ${ }^{(8)}$. この原 因として，ヤリは最高点に達した後，滑空状態になるためと解釈されている(9). このようなヤリとターボジャブ の飛距離の違いは, “羽あり”ターボジャブでは羽の存在によって抗力が増加することに加えて, 軸まわりの回転 に起因して滑空状態が起こりにくくなっていることが一因である可能性がある.

\section{（2）発射装置による射出}

まず，“羽あり”ターボジャブを発射装置により射出して行った投射実験の結果の例を図 11 に示す。初期条件 は表 3 の通りである。また，この条件を初期条件とする数值シミュレーションの結果を実線で，空気抵抗がない 場合の質点の運動を破線で示した.

図 11 より，発射装置を用いた投射実験では，ターボジャブの重心軌道も迎え角変化も数值シミュレーションに よりほぼ再現できることが分かる，表 3 に示すように，飛距離についても，投射実験，数值シミュレーション， および空気抵抗がない場合であまり大きな差がない結果となった。

次に，“羽なし”ターボジャブを発射装置により射出して行った投射実験の迎え角変化の例を図 12 に示す。こ の場合，迎え角は飛行中単調に増加しており，“羽なし”ターボジャブは一方向に回転しながら飛行していること が分かる. 図 12 の場合, “羽なし”ターボジャブは後尾を地面に着ける姿勢で地表面に達した。 
(a)

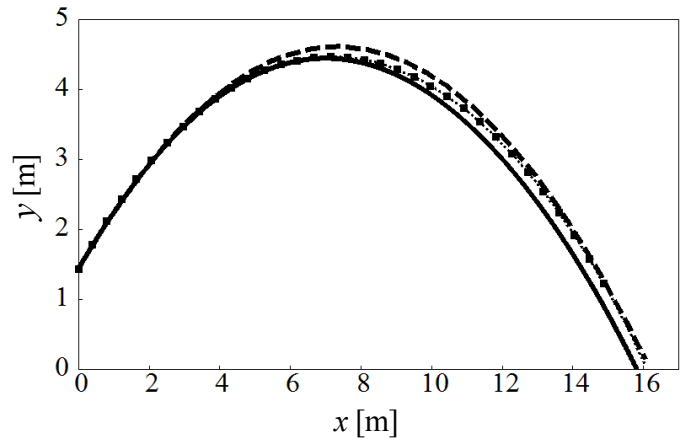

(b)

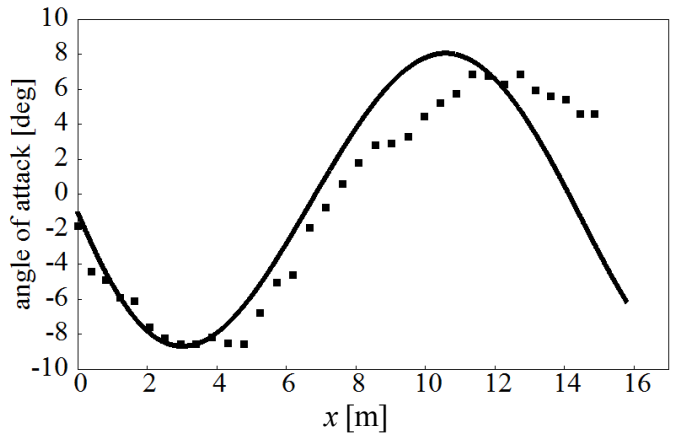

Fig. 11 (a) Trajectories of the center of mass, and (b) variations of the angle of attack for an intact turbo-jav (dotted line: throwing experiment launched by the launcher, solid line: numerical simulation, dashed line: no-drag case).

Table 3 Initial conditions and flying distance for a throwing experiment by the launcher.

\begin{tabular}{|c|c|c|}
\hline \multirow{6}{*}{ Initial conditions } & Release height & 1.43 \\
\hline & Initial velocity & 12.06 \\
\hline & Attitude angle & 39.88 \\
\hline & Angle of incidence & 40.88 \\
\hline & Angle of attack & -1.00 \\
\hline & Angular velocity & -1.37 \\
\hline \multirow{3}{*}{ Flying distance } & Throwing experiment & 16.06 \\
\hline & Numerical simulation & 15.80 \\
\hline & No-drag case & 16.05 \\
\hline
\end{tabular}

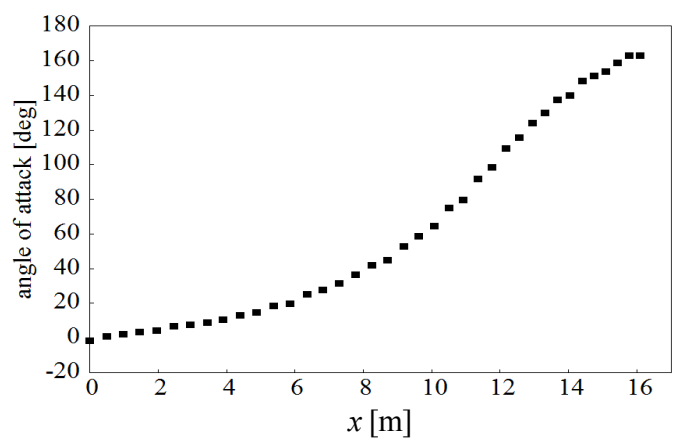

Fig. 12 The variation of angle of attack for a turbo-jav without fins launched by the launcher.

図 11 と図 12 の結果を比較すると, “羽あり”ターボジャブは羽があることにより飛行中に姿勢を安定に保つこ とが分かる.“羽あり”ターボジャブの場合は, 迎え角変化を抑える向きにモーメントが働く (図 9(c)○印) ため, 迎え角が 0 のまわりで振動しながら飛行している（図 11(b)）．それに対し，“羽なし”ターボジャブの場合は，迎 え角を戻す向きにモーメントは働かず (図 9(c)○印)，一方向に回転しながら飛んでいる（図 12)。そのため，“羽 なし”ターボジャブの飛行は“羽あり”ターボジャブに比べ不安定である. 前田らの先行研究(6)(7)において，“羽 あり”ターボジャブはヤリ ${ }^{(9)}$ と異なり比較的大きな迎え角や投射角の場合でも大きな飛距離が得られることがあ ると報告している。これは羽の存在によって飛行が安定化するためであると考えられる. 
図 9(c)の結果を用いて, 式(6)から“羽あり”ターボジャブの迎え角変化の周期を近似的に求めることができる. 図 9(c)より, $|\alpha|<10^{\circ}$ 範囲で $C_{\mathrm{m}}$ はほぼ直線と見なせることが分かる. 今, 角度は全てラジアンで表されている ものとし， $C_{\mathrm{m}}$ の近似直線の傾きを $A$ とすれば,

$$
C_{m} \approx-A \alpha \quad(A: \text { 定数 })
$$

と表すことができる. $\varphi=\alpha+\theta$ だから, $\mathrm{d}^{2} \varphi / \mathrm{d} t^{2}=\mathrm{d}^{2} \alpha / \mathrm{d} t^{2}+\mathrm{d}^{2} \theta / \mathrm{d} t^{2}$ である. 簡単のため, 近似的に

$$
\left.\mathrm{d}^{2} \theta / \mathrm{d} t^{2}=-B \quad \text { (ただし, } B=\text { 定数 }\right)
$$

と仮定すれば，式(3)を用いて式(6)は

$$
I \frac{\mathrm{d}^{2}}{\mathrm{~d} t^{2}} \alpha=-A^{\prime} \alpha+I B, \quad \text { ただし }, A^{\prime}=A \times \frac{1}{2} \rho U^{2} S \frac{l}{2}
$$

と表すことができる. 式(9)は， $\alpha=\alpha_{0}\left(=I B / A^{\prime}\right)$ まりの単振動を表す．振動の周期は

$$
T=2 \pi \sqrt{\frac{I}{A^{\prime}}}=2 \pi \sqrt{\frac{4 I}{A \rho U^{2} S l}}
$$

となる.

式(7)の $A$ の值を図 9(c)から決め，Uとして表 3 の初速度を用いることにすれば，図 11 に示した投射実験に対 応する迎え角振動の周期は, $1.68 \mathrm{sec}$ となった. この值は, 図 11(b)の迎え角変動と比較すると, 投射実験から得 られた半周期 $0.75 \mathrm{sec}$, 数值シミュレーションから得られた半周期 $0.83 \mathrm{sec}$ とほぼ一致した. ただし, 投射実験に おいてはカメラ画像のコマ数から時間を評価することで周期を求めた.

ここで，振動の中心 $\alpha_{0}(=I B / A)$ について少し検討しておく. 時刻 $t$ における重心速度を $\left(U_{\mathrm{x}}, U_{\mathrm{y}}\right)$ とすれば, $\theta$ の定義より，

$$
\theta=\tan ^{-1}\left(U_{y} / U_{x}\right)
$$

である. 図11(a)より投射害験における重心軌道は空気抵抗がない場合の質点の軌道に近いので, 簡単のため空気 抵抗がない場合の運動から $\alpha_{0}$ の概略值を評価すると， $\left|\alpha_{0}\right|$ の值は高々 $10^{-2} \mathrm{rad}$ 程度となった. 即ち，ほぼ迎え角 0 を中心にしてターボジャブは振動することが示された.

最後に, “羽あり”ターボジャブを投擲者が投げた場合の飛距離と数值シミュレーション結果に大きな違いが生 じた原因について考察する．発射装置による “羽あり”ターボジャブの飛行（重心軌道，迎え角変化，飛距離） と数值シミュレーション結果とがほぼ一致したのと対照的である.

発射装置では羽の 1 枚を溝に入れ，それと垂直な 2 枚の羽を発射台に沿わせて発射するため， 2 枚の羽が発射 台と平行で，残りの 2 枚の羽が鉛直となった状態で発射される．飛行中も 2 枚の羽が鉛直になった状態をほぼ保 っていることが撮影した画像から確かめられる。この姿勢は風洞実験における “羽あり”ターボジャブの姿勢と 同じである．角速度センサー（STT-IBS）を組み込んだ “羽あり”ターボジャブを試験的に投射して，軸まわり の回転運動について調べたところ，発射装置を用いた投射では飛行中のターボジャブの軸まわりの回転角速度は ほぼ 0 であった，一方，投擲者による投射では，角速度センサーの測定限界（34 rad/s）を超えた回転運動が起こ っており，計測ができなかった．投擲者が意図的に軸まわり回転を抑えて投射を行った場合でも測定限界に近い 回転運動が計測された．槍投げでは，リリース時においてヤリの軸まわりに 100〜150 rad/s（毎秒 16〜24 回転） の回転が起こっていることが報告されている(10). 以上のことから，投擲者による投射と数值シミュレーション結 果との差異は, “羽あり”ターボジャブの軸まわり回転の有無に起因寸ると推測される.

図 10(a) と表 2 において, 数值シミュレーションで得られた “羽あり”ターボジャブの飛距離の方が投擲者に よる実際の飛距離より大きくなったことは興味深い. 数值シミュレーション結果は軸まわりの回転がない場合の 飛距離とほぼ等しいことから，初期条件（初速度，投射角，迎え角）が同じであるならば，軸まわりの回転がな 
い方が飛距離が伸びることが示唆される. “羽あり”ターボジャブに軸まわりの回転が加わると, 羽が周囲の空気 の流れを乱すことで抗力が増加するために飛距離が伸びない可能性が考えられる.

\section{4. 結 論}

流体力学観点から有翼の飛翔体であるターボジャブの飛行特性を明らかにするために, 羽を切り落としたター ボジャブも併用して風洞実験によるターボジャブの空力特性の計測と, その計測結果に基づく数值シミュレーシ ヨンと投射実験による飛行軌道の解析を行った．軸まわりの回転がない場合では数值シミュレーション結果と投 射実験結果とはほぼ一致した，有翼のターボジャブは，羽の存在により姿勢を安定化する向きにピッチングモー メントが働き，迎え角を振動させながら飛行することが分かった．また，通常の投橂者による投射では軸まわり の回転が顕著であり, それに起因して空気抵抗がない場合より飛距離が小さくなることが示された.

本研究を遂行するに当たり，実験を手伝ってくれた院生山本翔平君，学部生山本健太君，山下大貴君，卒業生 平井啓太郎君, 橋本雅史君, 堀江雅則君に感謝寸る. 本研究の一部は, 科学研究費補助金 (基盤研究(B) 23360087), H22-23 年度関西大学重点領域研究助成金, 平成 24 年度関西大学大学院理工学研究科高度化推進研究費によって 行った.

\section{文献}

(1) Sunada, S., Yasuda, T., Yasuda, K., and Kawachi, K., "Comparison of Wing Characteristics at an Ultralow Reynolds Number", Journal of Aircraft, Vol. 39, No.2 (2002), pp.331-338.

（2）太田貴之, 梅村章, “水ロケットにおける飛行最適条件の研究”, 日本航空宇宙学会論文集, Vol. 49 (2001), pp.382-387.

(3) 渡辺力夫, 冨田信之, 竹前俊昭, “水ロケットの空力特性と飛行安定化について”, 日本航空宇宙学会論文集, Vol. 52 (2004), pp.449-455.

(4) 柴田洋一, 高松武男, “ペットボトルロケットの翼に関する考察”, 小山工業専門学校研究紀要, Vol. 36 (2005), pp.23-28.

(5) 板倉嘉哉, 本田祐基, “身近な遊具等の工学的解析（その 1 : ペットボトルロケットの推力特性）”, 千葉大学教育 学部研究紀要, Vol. 48 (2010), pp. 365-370.

(6) 丹松由美子, 前田正登, “ジャベリックスローにおけるターボジャブの投射初期条件に関する研究”, 日本機 械学会[No.07-24] シンポジウム講演論文集, (2007), pp. 234-238.

(7) 前田正登, 丹松由美子, “ジャベリックスローにおけるターボジャブの投射初期条件が飛距離に及ぼす影響”, スポーツ方法科学研究，Vol. 21, No.2 (2008), pp. 139-145.

(8) 前田正登, “やり投げにおけるヤリの飛行挙動”, Japanese Journal of Sports Science, Vol. 15 (1996), pp. 207-213.

(9) 池上康男, “やり投げ考”, Japanese Journal of Sports Science, Vol. 1 (1982), pp. 99-103.

(10) 石井喜八，西山哲成，“スポーツ動作学入門”，市村出版 (2002), pp.83-84. 